ASIMTOT: JURNAL KEPENDIDIKAN MATEMATIKA

Volume 1 Nomor 2, Juni - November 2019, halaman 93 - 104

Tersedia Daring pada https://journal.unwira.ac.id/index.php/ASIMTOT

\title{
DESAIN PEMBELAJARAN PADA MATERI HIMPUNAN MENGGUNAKAN MODEL PROBLEM BASED LEARNING
}

\section{LEARNING DESIGN IN SET MATERIAL USING PROBLEM BASED LEARNING MODEL}

\author{
Mesak Ratuanik \\ Sekolah Tinggi Keguruan dan Ilmu Pendidikan Saumlaki \\ mratuanik83@gmail.com
}

\begin{abstract}
Abstrak: Penelitian ini bertujuan untuk menghasilkan lintasan belajar untuk membelajarkan materi himpunan menggunakan model Problem Based Learning $(P B L)$. Penelitian ini dilaksanakan di SMP Kanisius Kalasan Yogyakarta pada bulan Septemeber-Desember 2018. Jenis penelitian ini merupakan penelitian desain. Subjek dalam penelitian ini adalah siswa kelas $\mathrm{VII}_{\mathrm{C}}$ (kelas uji coba) dan siswa kelas $\mathrm{VII}_{\mathrm{A}}$ (kelas penelitian). Hasil penelitian menunjukan bahwa:lintasan belajar dengan model $P B L$ sebagai berikut: (a) Peneliti menyampaikan tujuan pembelajaran dan agar siswa dapat mengatur strategi dalam menyelesaikan masalah sesuai tujuan pembelajaran dan peneliti memberikan masalah nyata secara lisan dengan konteks didalam kelas tentang operasi himpunan (irisan dan gabungan); (b) Peneliti membentuk siswa dalam kelompok dan memberikan masalah terkait materi operasi himpunan (irisan dan gabungan); (c) Selanjutnya peneliti mendampingi siswa; (d) Setelah siswa selesai menyelesaikan masalah, selanjutnya dipresentasikan (e) Kemudian peneliti dan siswa mengevaluasi proses penyelesaian masalah oleh siswa. (f) Selanjutnya peneliti memberikan tes yang berkaitan dengan masalah nyata terkait dengan materi operasi himpunan (irisan dan gabungan) untuk dianalisis berdasarkan kemampuan pemecahan masalah siswa.
\end{abstract}

Kata Kunci: Problem Based Learning, Kemampuan Pemecahan Masalah, Penelitian Desain.

Abstract: This research aims to produce a learning trajectory for learning set material using the Problem Based Learning $(P B L)$ model. This research was carried out at Yogyakarta Kalasan Kanisius Middle School in September-December 2018. This type of research is a design research. The subjects in this research were students of class $\mathrm{VII}_{C}$ (test class) and students of class $\mathrm{VII}_{A}$ (research class). The results showed that the learning trajectory with the PBL model was as follows: (a) The researcher conveyed the learning objectives and so students could set strategies in solving problems according to the learning objectives and the researchers gave real problems verbally to the context in the classroom about set operations (slices) and combined); (b) The researcher forms students in groups and gives problems related to the set operation material (slices and joints); (c) Next, the researcher accompanies students; (d) After students finish solving the problem, then presented (e) Then the researcher and students evaluate the problem solving process by students. (f) Next the researcher provides tests relating to real problems related to the set operation material (slices and joints) to be analyzed based on students' problem solving abilities

Keywords: Problem based Learning, Problem Solving skill, Design Research.

Cara Sitasi: Ratuanik, M. (2019). Desain Pembelajaran Pada Materi Himpunan Menggunakan Model Problem based Learning. Asimtot: Jurnal Kependidikan Matematika, “1”(“2”), “ 93 - 104 ” 
Berdasarkan wawancara dengan guru mata pelajaran matematika pada tahun 2018, dalam proses pembelajaran guru masih menggunakan metode konvensional dalam kegiatan belajar mengajar dimana guru menjelaskan dan memberikan materi dan siswa duduk diam, mendengarkan materi, menerima rumus, mengerjakan soal latihan.

Guru mengatakan juga bahwa, siswa mengalami kesulitan dalam menyelesaikan soalsoal nonrutin. Sebagian besar siswa mengalami kesulitan dalam memodelkan situasi nyata kemasalah matematika dan tidak memahami makna dari simbol-simbol yang digunakan dalam menyelesaikan soal yang berkaitan dengan operasi himpunan (irisan dan gabungan). Siswa cenderung melewati soal yang membutuhkan analisis permasalahan. Selama pembelajaran, tak jarang siswa menunggu guru untuk menjelaskan atau menunggu teman mengerjakan didepan kelas. Siswa kurang mandiri dan cenderung membutuhkan waktu yang cukup lama untuk belajar. Kegiatan seperti ini yang menyebabkan siswa pasif, kurang termotivasi dalam memahami dan mengaplikasi konsep matematika. Akibatnya, siswa terkesan pasif dan mengalami kesulitan dalam memahami dan mempelajari materi tersebut.

Pada standar isi mata pelajaran matematika tahun 2006 dinyatakan bahwa salah satu aspek penting yang dipelajari oleh siswa adalah kemampuan pemecahan masalah (Wardhani, S. 2010). Oleh karena itu diperlukan pengajaran yang dapat memacu kemampuan siswa dalam memecahkan masalah matematika. Melalui kemampuan pemecahan masalah, siswa dimungkinkan untuk memperoleh pengalaman menggunakan pengetahuan serta ketrampilan yang sudah dimiliki untuk diterapkan pada pemecahan suatu permasalahan.

Berdasarkan latar belakang tersebut, maka penulis ingin meneliti tentang bagaimana lintasan belajar untuk membelajarkan materi operasi himpunan (irisan dan gabungan) menggunakan model problem based learning untuk siswa kelas VII SMP Kanisius Kalasan Yogyakarta?

Problem based learning adalah model pembelajaran yang dirancang agar siswa siswa melatih kemampuan dalam memecahkan masalah Setyorini, dkk., (2011). Dengan model problem based learning, pembelajaran akan mengakibatkan siswa sehingga lebih mampu dalam memecahkan masalah yang dihadapinya. Dengan demikian, kemampuan pemecahan masalah akan meningkat secara otomatis. Tahap dalam pembelajaran berdasarkan masalah adalah sebagai berikut.

Tabel 1. Tahapan Problem Based Learning

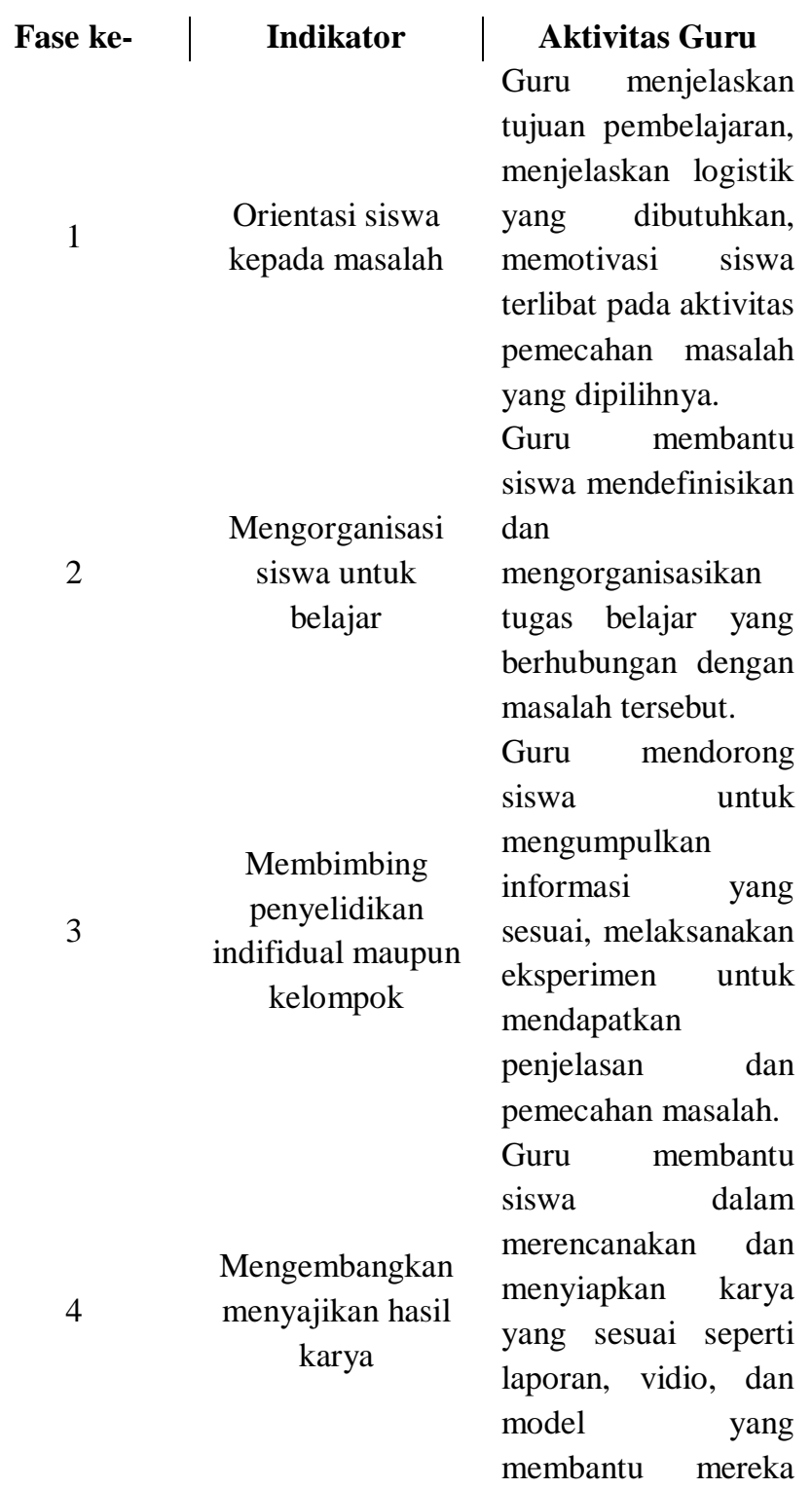


untuk berbagi tugas

dengan temannya.

Guru membantu

siswa untuk

melakukan refleksi

Menganalisis dan mengevaluasi

proses pemecahan masalah atau evaluasi

terhadap

penyelidikan mereka

dan proses-proses

yang mereka

gunakan.

Sumber: (Trianto, 2007: 71)

Dengan demikian, peneliti menyimpulkan bahwa Problem Based Learning adalah model pembelajaran yang menjadikan masalah sebagai dasar dari suatu proses pembelajaran. Masalah yang diambil dalam Problem Based Learning merupakan masalah dalam kehidupan nyata.

\section{Metode Penelitian}

Jenis peneltian yang digunakan dalam penelitian ini Plomp (2007) adalah penelitian desain. Analisis data dalam penelitian ini menggunakan model Miles dan Huberman (Sugiyono, 2018:92), mencakup 3 aktivitas analisis datanya, yaitu: reduksi data, penyajian data dan penarikan kesimpulan.

\section{Hasil Penelitian dan Pembahasan}

Hasil penelitian yang disajikan dalam artikel ini dibatasi oleh peneliti pada tahap pertama dari desain penelitian. Tujuan dari desain yan g dibuat oleh peneliti adalah agar siswa dapat mengetahui tentang konsep irisan dan gabungan menggunakan model PBL. Kegiatan siswa dan

guru dalam pembelajaran ini menggunakan model PBL adalah sebagai berikut:

\section{Pertemuan Pertama}

Fase 1 : Orientasi Siswa terhadap Masalah

Guru mengawali pembelajaran dengan mengecek kesiapan siswa, kesiapan kelas, dan menyampaikan tujuan pembelajaran.

a. Jika ada siswa tidak dapat menyebutkan kembali materi terakhir yang telah mereka pelajari dan tidak ada siswa yang dapat menyebutkan pengertian himpunan.

b. Jika guru bertanya kepada siswa tentang jawaban mereka, maka itu tidak berarti jawabannya tidak benar, tetapi guru ingin mengetahui proses berpikir siswa.

c. Guru membagikan siswa dalam beberapa kelompok.

d. Guru mengilustrasikan masalah kepada siswa. Masalah yang dibuat dapat disajikan dalam bentuk table.

\section{Fase 2: Mengorganisasi Siswa Untuk Belajar}

a. Guru menunjuk dua siswa untuk menyebutkan 5 mata pelajaran yang disukai. Berikut ini adalah hasil kedua siswa yang menyebutkan mata pelajaran yang disukai.

Tabel 2:

\begin{tabular}{|c|c|}
\hline Nama & Mata Pelajaran yang disukai \\
\hline Andi & $\begin{array}{c}\text { Matematika, Agama, Bhs. } \\
\text { Indonesia, IPS, Olahraga }\end{array}$ \\
\hline Bunga & $\begin{array}{c}\text { Bhs. Indonesia, Matematika, } \\
\text { Bhs.Inggris, Olahraga, IPA }\end{array}$ \\
\hline
\end{tabular}

b. Guru menanyakan kepada siswa apa kategori yang tepat untuk Andi, dan Bunga? Kemudian kategori apa yang tepat untuk Matematika, Agama, Bhs. Indonesia, IPS, Olahraga, IPA, Bhs.Inggris?

\section{Kemungkinan 1:}

Siswa tidak dapat menyatakan himpunan nama dan himpunan mata pelajaran. 


\section{Kemungkinan 2:}

Siswa dapat menyatakan himpunan nama yaitu;

- Andi dan himpunan mata pelajaran yaitu \{Matematika, Agama, Bhs. Indonesia, IPS, Olahraga .

- Bunga dan himpunan mata pelajaran yaitu \{Bhs.Indonesia, Matematika, Bhs.Inggris, Olahraga, IPA\}

Kemungkinan 3:

Siswa tidak dapat menyatakan hubungan Andi dengan Matematika, Agama, Bhs. Indonesia, IPS, Olahraga.

Kemungkinan 4:

Siswa dapat menyatakan hubungan Andi dengan Matematika,Agama,Bhs. Indonesia, IPS, Olahraga yaitu“mata pelajaran yang disukai"

\section{Kemungkinan 5:}

Siswa dapat menyatakan himpunan nama yaitu

- Andi dan himpunan mata pelajaran yaitu \{Matematika, Agama, Bhs.Indonesia, IPS, Olahraga

- Bunga dan himpunan mata pelajaran yaitu \{Bhs.Indonesia, Matematika, Bhs.Inggris, Olahraga\}

- Andi dan Bunga mempunyai himpunan mata pelajaran yang disukai yaitu $\{$ Bhs.Indonesia,

\section{Kemungkinan 6:} Matematika, Olahraga $\}$

$\mathrm{A}=\{$ Matematika, Agama, Bhs. Indonesia, IPS, Olahraga

$\mathrm{B}=\{$ Bhs. Indonesia, Matematika, Bhs Inggris, Olahraga

$\mathrm{C}=\{$ Bhs. Indonesia, Matematika Olahragaa $\}$

\section{Fase 3: Membimbing penyelidikan indifidual maupun kelompok.}

a. Guru berkeliling untuk memantau proses penyelesaian soal yang dilakukan oleh masingmasing kelompok dengan berkeliling di dalam kelas dan berdialog dengan siswa.

b. Guru mengajukan pertanyaan yang dapat merangsang siswa untuk memecahkan jawaban siswa, misalnya:

1. Guru menanyakan kepada siswa apa kategori yang tepat untuk Andi, dan Bunga? Kemudian kategori apa yang tepat untuk Matematika, Agama, Bhs. Indonesia, IPS, Olahraga, IPA, Bhs.Inggris? Jika siswa sudah menjawab "nama" dan "mata pelajaran yang disukai", maka selanjutnya bimbinglah siswa untuk menuliskan nama- nama dan mata pelajaran tersebut dengan tanda pemisah koma (,). Setelah itu, bimbing siswa untuk menambahkan kurung kurawal di awal dan diakhir kategori tersebut. Ketika siswa selesai menuliskannya, guru menanyakan kepada siswa bagaimanakah cara membacanya. Adapun jawaban yang diharapkan guru (sesuai dengan kemungkinan 2) adalah: "himpunan nama adalah Andi dan Bunga sedangkan himpunan mata pelajaran yang disukai adalah Bahasa Indonesia, Matematika, Bahasa Inggris, Olahraga, IPA".

2. Guru menanyakan kepada siswa apa hubungan Andi dengan Matematika, Agama, Bhs.Indonesia, IPS, Olahraga? Apa hubungan Bunga dengan Bhs. Indonesia, Matematika, Bhs.Inggris, Olahraga, IPA? Jawaban yang diharapkan guru adalah "mata pelajaran yang disukai" sesuai Kemungkinan 4.

3. Guru memberikan pertanyaan pancingan seperti ini: apakah kamu dapat menuliskan himpunan baru yang anggota himpunannya adalah mata pelajaran yang disukai Andi dan Bunga? Jawaban yang diharapkan guru sesuai kemungkinan 5. Guru melanjutkan pertanyaan pancingan lagi sehingga siswa dapat menuliskan dengan simbol himpunan-himpunan tersebut dengan memisalkan nama dari 
himpunan tersebut? Jawaban yang diharapkan guru sesuai dengan Kemungkinan 6. Selain itu, guru juga dapat mengarahkan siswa untuk menyebutkan lambang atau simbol"irisan". Dikarenakan lambang atau simbol irisan tersebut belum dipelajari sebelumnya.. Kemudian guru memberikan rangsangan kepada siswa agar dapat mendefinisikan irisan sesuai bahasa siswa yang mudah dipahami.

Fase 4: Mengembangkan Dan Menyajikan Hasil Karya

a. Guru mengecek pemahaman siswa dengan bertanya.

b. Guru memberikan apresiasi kepada siswa karena telah memahami masalah dengan benar, yaitu dapat menyebutkan apa yang diketahui dan yang ditanyakan dari masalah yang diberikan.

c. Guru memberikan apresiasi kepada siswa karena telah menuliskan rencana penyelesian masalah sesuai yang mereka pahami dari maksud soal yang ada. Kemudian guru memberikan motivasi kepada siswa untuk melanjutkan langkah selanjutnya sesuai dnegan rencana yang telah dibuat oleh siswa.

\section{Fase 5: Menganalisa Dan Mengevaluasi Proses Pemecahan Masalah}

a. Guru membantu siswa untuk melakukan refleksi atau evaluasi terhadap penyelidikan mereka dan proses-proses yang mereka kerjakan.

b. Guru mengarahkan siswa untuk menyimpulkan materi yang sudah dipelajari.

c. Siswa dapat menyimpulkan materi yang sudah dipelajari bersama dengan interaksi guru, yaitu Irisan A dan B adalah suatu himpunan yang anggotaanggotanya merupakan anggota himpunan A dan sekaligus merupakan anggota himpunan $\mathrm{B}$ dan dilambangkan dengan $A \cap B$.

\section{Pertemuan Kedua}

\section{Fase 1 : Orientasi Siswa terhadap Masalah}

Guru mengawali pembelajaran dengan mengecek kesiapan siswa, kesiapan kelas, dan menyampaikan tujuan pembelajaran.

a. Jika ada siswa tidak dapat menyebutkan kembali materi terakhir yang telah mereka pelajari dan tidak ada siswa yang dapat menyebutkan pengertian himpunan.

b. Jika guru bertanya kepada siswa tentang jawaban mereka, maka itu tidak berarti jawabannya tidak benar, tetapi guru ingin mengetahui proses berpikir siswa.

c. Guru mengilustrasikan masalah kepada siswa. Masalah yang dibuat dapat disajikan dalam bentuk table.

Fase 2: Mengorganisasi Siswa Untuk Belajar

a. Guru menunjuk dua siswa untuk menyebutkan 5 mata pelajaran yang disukai. Berikut ini adalah hasil kedua siswa yang menyebutkan mata pelajaran yang disukai.

Tabel 3:

\begin{tabular}{|c|c|}
\hline Nama & Mata Pelajaran yang disukai \\
\hline Andi & $\begin{array}{c}\text { Matematika, Agama, Bhs. } \\
\text { Indonesia, IPS, Olahraga }\end{array}$ \\
\hline Bunga & $\begin{array}{c}\text { Bhs. Indonesia, Matematika, } \\
\text { Bhs.Inggris, Olahraga, IPA }\end{array}$ \\
\hline
\end{tabular}

b. Guru menanyakan kepada siswa apa kategori yang tepat untuk Andi, dan Bunga? Kemudian kategori apa yang tepat untuk Matematika, Agama, Bhs. Indonesia, IPS, Olahraga, IPA, Bhs. Inggris?

\section{Kemungkinan 1:}

Siswa tidak dapat menyatakan himpunan nama dan himpunan mata pelajaran. 


\section{Kemungkinan 2:}

Siswa dapat menyatakan himpunan nama yaitu

- Andi dan himpunan mata pelajaran yaitu \{Matematika, Agama, Bhs. Indonesia, IPS, Olahraga .

- Bunga dan himpunan mata pelajaran yaitu \{Bhs.Indonesia, Matematika, Bhs.Inggris, Olahraga, IPA \}

\section{Kemungkinan 3:}

Siswa tidak dapat menyatakan hubungan Andi dengan Matematika, Agama, Bhs. Indonesia, IPS, Olahraga.

\section{Kemungkinan 4:}

Siswa dapat menyatakan hubungan Andi dengan Matematika,Agama,Bhs. Indonesia, IPS, Olahraga yaitu"mata pelajaran yang disukai"

\section{Kemungkinan 5:}

Siswa dapat menyatakan himpunan nama yaitu

- Andi dan himpunan mata pelajaran yaitu \{Matematika, Agama, Bhs.Indonesia, IPS, Olahraga

- Bunga dan himpunan mata pelajaran yaitu Bhs.Indonesia, Matematika, Bhs.Inggris, Olahraga\}

- Andi dan Bunga mempunyai himpunan mata pelajaran yang disukai yaitu \{matematika, Agama, Bhs Indo, IPS, Olahraga, Ghs Inggris

\section{Kemungkinan 6:}

$\mathbf{A}=$ Matematika, Agama, Bhs.Indonesia, IPS, Olahraga .

$\mathrm{B}=$ Bhs.Indonesia, Matematika, Bhs.Inggris, Olahraga\}

\section{Kemungkinan 7:}

$\mathbf{A}=\{$ Matematika, Agama, Bhs.Indonesia, IPS, Olahraga .

$\mathrm{B}=\{$ Bhs.Indonesia, Matematika, Bhs.Inggris, Olahraga

$\mathrm{C}=\{$ Matematika, Agama, Bhs Indo, IPS, Olahraga, Bhs Inggris $\}$.

\section{Fase 3: Membimbing penyelidikan indifidual maupun kelompok}

a. Guru berkeliling untuk memantau proses penyelesaian soal yang dilakukan oleh masing-masing kelompok dengan berkeliling di dalam kelas dan berdialog dengan siswa. b. Guru mengajukan pertanyaan yang dapat merangsang siswa untuk memecahkan jawaban siswa, misalnya:

1. Guru menanyakan kepada siswa apa kategori yang tepat untuk Andi, dan Bunga? Kemudian kategori apa yang tepat untuk Matematika, Agama, Bhs. Indonesia, IPS, Olahraga, IPA, Bhs.Inggris? Jika siswa sudah menjawab "nama" dan "mata pelajaran yang disukai”, maka selanjutnya bimbinglah siswa untuk menuliskan nama- nama dan mata pelajaran tersebut dengan tanda pemisah koma (,). Setelah itu, bimbing siswa untuk menambahkan kurung kurawal di awal dan diakhir kategori tersebut. Ketika siswa selesai menuliskannya, guru menanyakan kepada siswa bagaimanakah cara membacanya? Adapun jawaban yang diharapkan guru (sesuai dengan kemungkinan 2) adalah: "himpunan nama adalah Andi dan Bunga sedangkan himpunan mata pelajaran yang disukai adalah Bahasa Indonesia, Matematika, Bahasa Inggris, Olahraga, IPA".

2. Guru menanyakan kepada siswa apa hubungan Andi dengan Matematika, Agama, Bhs.Indonesia, IPS, Olahraga? Apa hubungan Bunga dengan Bhs. Indonesia, Matematika, Bhs.Inggris, Olahraga, IPA? Jawaban yang diharapkan guru adalah "mata pelajaran yang disukai" sesuai Kemungkinan 4.

3. Guru memberikan pertanyaan pancingan seperti berikut ni: apakah kamu dapat menuliskan himpunan baru yang anggota himpunannya 
adalah mata pelajaran yang disukai Andi dan Bunga? Jawaban yang diharpkan guru sesuai kemungkinan 5.

4. Guru melanjutkan pertanyaan pancingan lagi sehingga siswa dapat menuliskan dengan simbol himpunan-himpunan tersebut dengan memisalkan nama dari himpunan tersebut? Jawaban yang diharapkan guru sesuai dengan Kemungkinan 6.

5. Guru memberikan topangan kepada siswa seperti berikut ini: coba periksa anggota himpunan A dan himpunan $\mathrm{B}$, ambil elemen pertama dari A kemudian cocokkan dengan anggota himpunan B. Jika ada yang sama, hapus elemen tersebut dari himpunan A. Jika tidak ada yang sama, lanjut ke elemen berikutnya. Ulangi proses tersebut untuk elemen kedua, ketiga sampai semua elemen $\mathrm{C}$ telah selesai dicocokkan. Semua elemen himpunan A ditambahkan dengan sisa elemen himpunan B merupakan gabungan himpunan $\mathrm{A}$ dengan himpunan C. Jawaban yang diharpkan guru sesuai kemungkinan 7. Selain itu, guru juga dapat menunjukan kepada siswa apa itu simbol "gabungan". Kemudian guru memberikan rangsangan kepada siswa agar dapat mendefinisikan gabungan sesuai bahasa siswa yang mudah dipahami.

\section{Fase 4: Mengembangkan Dan Menyajikan Hasil Karya}

a. Guru mengecek pemahaman siswa dengan bertanya. b. Guru memberikan apresiasi kepada siswa karena telah memahami masalah dengan benar, yaitu dapat menyebutkan apa yang diketahui dan yang ditanyakan dari masalah yang diberikan.

c. Guru memberikan apresiasi kepada siswa karena telah menuliskan rencana penyelesian masalah sesuai yang mereka pahami dari maksud soal yang ada. Kemudian guru memberikan motivasi kepada siswa untuk melanjutkan langkah selanjutnya sesuai dnegan rencana yang telah dibuat oleh siswa.

\section{Fase 5: Menganalisa Dan Mengevaluasi Proses Pemecahan Masalah}

a. Guru membantu siswa untuk melakukan refleksi atau evaluasi terhadap penyelidikan mereka dan proses-proses yang mereka kerjakan.

b. Guru mengarahkan siswa untuk menyimpulkan materi yang sudah dipelajari.

c. Siswa dapat menyimpulkan materi yang sudah dipelajari bersama dengan interaksi guru, yaitu: Gabungan himpunan A dan B adalah suatu himpunan yang anggotanya terdiri dari anggota himpunan $\mathrm{A}$ atau anggota himpunan B. Dilambangkan dengan $A \cup B$

\section{Deskripsi Kemampuan Pemecahan Masalah Siswa \\ Peneliti memberikan masalah untuk mengetahui kemampuan pemecahan masalah siswa yang berkaitan dengan irisan dan gabungan yang telah dipelajari sebelumnya. Adapun hasil pemecahan masalah siswa sebagai berikut.}




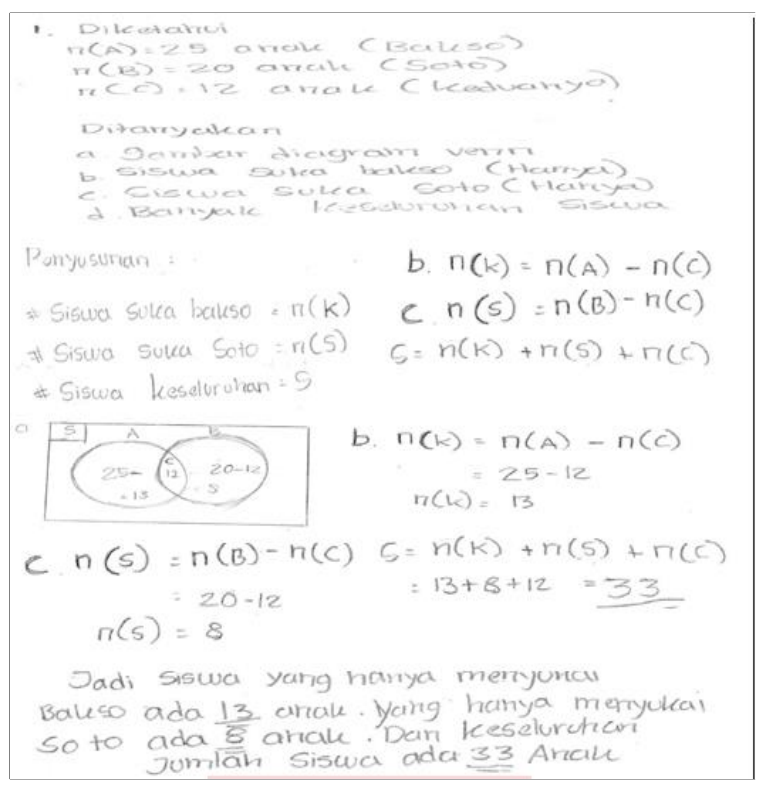

Gambar 1. Hasil Pekerjaan Siswa 1 (S1)

Berdasarkan apa yang ditulisakan oleh $\mathrm{S} 1$, bahwa S1 telah memahami soal, dengan menuliskan apa yang diketahui dan yang ditanyakan pada soal. Dalam menuliskan apa yang diketahui, S1 menyimbolkan banyaknya siswa yang suka makan bakso yaitu $\mathrm{n}(\mathrm{A})$, banyak siswa yang suka makan soto yaitu $\mathrm{n}$ (B) dan banyak siswa suka makan keduanya yaitu $\mathrm{n}(\mathrm{C})$. S1 juga menuliskan apa yang ditanyakan dari masalah tersebut. Berikut ini kutipan wawancara dengan S1:

P: Dari soal nomor 1, apa yang diketahui ?

S1: Ada yang suka makan bakso yaitu 25 siswa yang diibarkarkan $n(A)$, yang suka makan soto ada 20 diibartkan dengan $n(B)$ dan suka keduanya 12 diibarkan dengan $n(C)$.

P: Apa saja yang ditanyakan dari soal nomor 1 ?

S1: Siswa membaca apa yang telah dituliskan pada lembar jawabannya.

P: Coba kamu ceritakan kembali maksud dari soal nomor 1!

S1: Cari berapa banyak siswa yang suka makan bakso saja, siswa yang suka makan soto saja dan banyaknya siswa dalam kelas tersebut.
Dalam merencanakan masalah, S1 menggunakan simbol matematika untuk menyelesaikan masalah tersebut. S1 dapat merencanakan penyelesaian dengan menggunakan konsep operasi irisan dua buah himpunan. Berikut ini penggalan wawancara dengan S1:

$P$ : konsep apa yang digunakan untuk menyelesaikan soal tersebut?

S1: menggunakan konsep operasi irisan.

P: Tujuan kamu menuliskan siswa suka bakso sama dengan $n(K)$ terus $n(S)$ dan $S$ itu untuk apa?

S1: aku misalkan pak, tapi yang seharusnya siswa yang hanya suka bakso adalah $n(K)$, siswa yang hanya suka soto adalah $n(S)$ pak.

Berdasarkan hasil jawaban S1, untuk point (a) terlihat bahwa S1 menggambarkan diagram venn dengan benar. S1 menggambarkan diagram venn dengan dua buah himpunan yang diberi keterangan dari diagram A sebagai himpunan banyaknya siswa yang menyukai bakso (A) dan diagram B sebagai himpunan banyaknya siswa yang menyukai soto (B). Pada diagram (A), S1 menuliskan dalam diagram venn (B) 25 dan 13, pada diagram $S, S 1$ menuliskan 20-12 dan 8 dan pada lingkaran tengah yaitu irisan dari diagram A dan B yaitu 12 yang menerangkan bahwa banyaknya siswa yang menyukai keduanya. Setelah menggambarkan diagram venn, S1 menentukan berapa banyak siswa yang hanya menyukai bakso yang dimisalkan dengan $\mathrm{n}(\mathrm{K})$ pada point (b) sesuai dengan rencana yang telah dilakukan sebelumnya, yaitu mengurangkan banyaknya siswa yang menyukai bakso $\mathrm{n}(\mathrm{A})$ dengan banyaknya siswa yang menyukai keduanya $\mathrm{n}(\mathrm{C})$ sebagai berikut $25-12=13$ siswa. Selanjutnya untuk menjawab point (c), yaitu banyaknya siswa yang hanya menyukai soto $\mathrm{n}(\mathrm{S})$ adalah banyaknya siswa yang menyukai soto $n(B)$ 
dikurangi dengan banyaknya siswa yang menyukai keduanya $n(C)$ sebagai berikut $20-12=8$ siswa. Kemudian untuk menghitung berapa banyak siswa dalam kelompok tersebut yang disimbolkan dengan S, S1 menjumlahkan banyaknya siswa yang hanya menyukai bakso $\mathrm{n}(\mathrm{K})$, banyaknya siswa yang hanya menyukai soto $\mathrm{n}(\mathrm{S})$ dan banyaknya siswa yang menyukai keduanya $\mathrm{n}(\mathrm{C})$ yaitu $13+8+12=33$ siswa.

S1 juga dapat menyimpulkan hasil pekerjaannya, dengan menuliskan banyaknya siswa yang suka bakso saja adalah 13 siswa, yang suka soto saja adalah 8 siswa dan banyak siswa dalam kelompok adalah 33 siswa. Hal tersebut diperkuat dengan wawancara dengan S1 sebagai berikut:

P: Coba dijelaskan cara anda dalam menyelesaikan soal nomor 1 ?

S1: Untuk a, gambarkan diagram venn, jadi ada dua lingkaran buah himpunan yaitu 25 siswa suka soto, 20 siswa yang suka bakso dan 12 siswa ditengah-tengahnya.

P: Didalam lingkaran B itu ada 25 dan 13 itu menunjukan apa?

S1: Jadi 25 itu adalah siswa yang suka makan bakso, 13 itu siswa yang hanya suka makan bakso saja.

P: Yang 12, 8 merupakan apa?

S1: 12 itu merupakan siswa yang suka suka makan keduanya. 8 itu merupakan siswa yang hanya suka makan soto saja.

P: Yang 12 itu merupakan apa dari B dan S?

S1: Merupakan irisan.

P: Untuk point $b$ ?

S1: $n(K)$ itu saya ibaratkan siswa yang hanya suka bakso saja jadi siswa yang suka bakso saya ibaratkan $n(A)$ kurang siswa yang suka keduanya yang saya ibararkan $n(C)$. Jadi 25 $12=13$ siswa.

P: Untuk point c?

S1: $n(S)$ itu diibaratkan siswa yang hanya suka soto saja jadi siswa yang suka soto yang diibaratkan dengan $n(B)$ kurang siswa yang suka keduanya yang didibaratkan $n(C)$. Jadi 20-12=8 siswa.

$P$ : yang $d$ ?

S1: $S$ itu saya ibaratkan semesta. Jadi saya jumlahkan siswa yang hanya suka bakso yang saya sudah dapat pada point b yaitu $n(K)=13$ dengan siswa yang hanya suka soto saja pada point c yaitu $n(S)=8$ dan siswa yang suka keduanya yaitu $n(C)=12$. Jadi hasilnya 33 siswa.

P: Dari nomor 1 ini, sudah yakin jawabanya benar?

S1: Sudah pak. Hanya suka makan bakso saja itu 13 dijumlahkan dengan 12 jadi 25 siswa yang suka bakso. Siswa yang hanya suka makan soto saja itu 8 dan dijumlahkan dengan 13 jadi ada 20 siswa yang suka makan soto. Dijumlahkan yang hanya suka makan bakso, soto dan suka keduanya hasilnya 33 siswa semua yang ada didalam kelompok itu.

$P$ : Bagaimana kesimpulannya?

S1: Jadi banyak siswa yang hanya suka makan bakso saja ada 13 siswa, banyak siswa yang hnaya suka makan soto saja ada 8 siswa, sedangkan banyak siswa dalam kelompok itu ada 33 siswa.

Berdasarkan hasil jawaban siswa dan wawancara S1 pada masalah 1, maka disimpulkan bahwa, S1 sudah memiliki kemampuan pemecahan masalah dalam menyelesaikan masalah dalam kehidupan sehari-hari yang berkaitan dengan operasi himpunan (irisan) dua buah himpunan, yaitu memahami masalah (understanding the problem), hal ini ditunjukkan dari kemampuan S1 mengidentifikasi kecukupan data untuk memecahkan masalah dengan menyebutkan informasi-informasi yang diberikan dari pertanyaan yang diajukan yakni unsur-unsur yang diketahui dari soal dan apa yang ditanyakan dari soal. Merencanakan penyelesain (devicing a plan), hal ini ditunjukkan dari kemampuan subjek membuat 
model matematika dari masalah yang diberikan. S1 mempunyai rencana metode memecahkan dengan menunjukkan bahwa untuk memecahkan masalah tersebut akan dipilih salah satu metode penyelesaian. Menyelesaikan sesuai rencana (carrying out the plan), S1 mampu melakukan rencana pemecahan masalah dengan menunjukkan langkah-langkah menyelesaikan masalah menggunakan strategi yang dipilih yakni operasi irisan dua buah himpunan sehingga diperoleh penyelesaian dari masalah tersebut banyaknya siswa yang suka bakso saja adalah 13 siswa, yang suka soto saja adalah 8 siswa dan banyak siswa dalam kelompok adalah 33 siswa. Memeriksa kembali (looking back), S1 mampu memeriksa kembali kebenaran kesimpulan yang diperoleh dengan menunjukkan cara memeriksa kebenaran jawaban yakni menguji kembali nilai yang diperoleh pada kesimpulan.

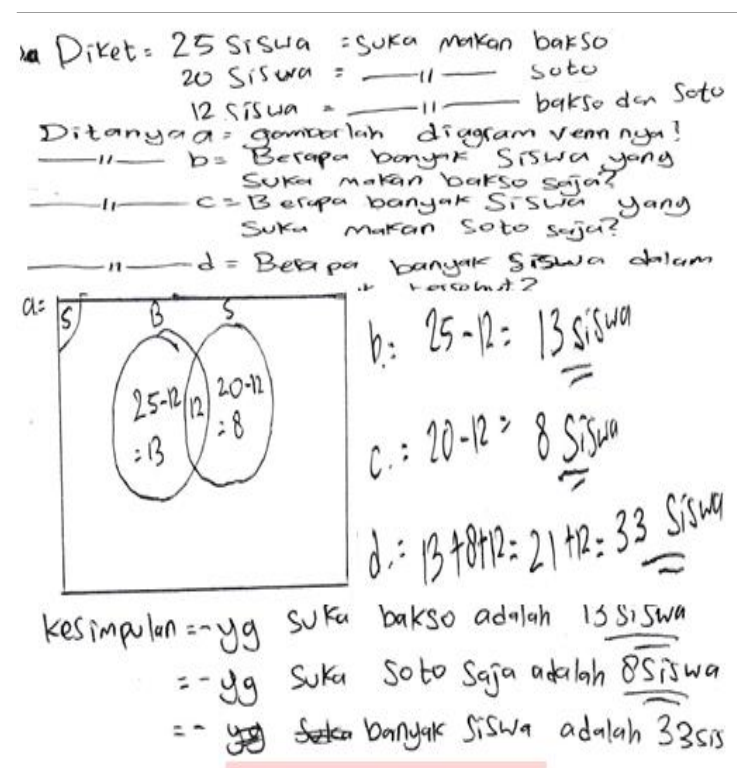

Gambar 2. Hasil Pekerjaan Siswa 2 (S2)

Berdasarkan apa yang ditulisakan oleh S2, bahwa S2 telah memahami soal, dengan menuliskan apa yang diketahui dan yang ditanyakan pada soal. Dalam menuliskan apa yang diketahui, S2 tidak menyimbolkan tetapi memberikan keterangan dari apa yang diketahui, yaitu banyaknya siswa yang suka makan bakso, banyak siswa yang suka makan soto dan banyak siswa suka makan keduanya. S2 juga menuliskan apa yang ditanyakan dari masalah tersebut. Berikut ini kutipan wawancara dengan S2:

\section{P: Dari soal nomor 1, apa yang diketahui?}

S2: sambil membaca soal, siswa menjawab 25 siswa suka makan bakso, 20 siswa suka makan soto dan 12 siswa suka makan bakso dan soto.

P: apa saja yang ditanyakan dari soal nomor 1 ?

S2: siswa membaca soal

Dalam merencanakan masalah, S2 tidak menggunakan simbol matematika untuk menyelesaikan masalah tersebut. Tetapi berdasarkan wawancara dengan S2, S2 dapat merenakan penyelesaian dengan menggunakan konsep operasi irisan dua buah himpunan. Berikut ini penggalan wawancara dengan S2:

$P$ : Konsep apa yang digunakan untuk menyelesaikan soal tersebut?

S2: Menggunakan konsep irisan.

Berdasarkan hasil jawaban S2, untuk point (a) terlihat bahwa S2 menggambarkan diagram venn dengan benar. S2 menggambarkan diagram venn dengan dua buah himpunan yang diberi keterangan dari bakso (B) dan soto (S) dan menuliskan 25-12=13 pada diagram (B) yang menunjukan bahwa hanya 13 siswa yang menyukai bakso dan pada diagram B, S2 menuliskan $20-12=8$ siswa yang menyukai soto sedangkan 12 merupakan irisan dari kedua diagram tersebut yang merupakan banyaknya siswa yang menyukai keduanya.

Setelah menggambarkan diagram venn, S2 menentukan berapa banyak siswa yang hanya menyukai bakso pada point (b), yaitu mengurangkan banyaknya siswa yang menyukai bakso dengan banyaknya siswa yang menyukai keduanya sebagai berikut $25-12=13$ siswa. Selanjutnya untuk menjawab point (c), yaitu 
banyaknya siswa yang hanya menyukai soto adalah banyaknya siswa yang menyukai soto dikrangi dengan banyaknya siswa yang menyukai keduanya sebagai berikut $20-12=8$ siswa. Kemudian untuk menghitung berapa banyak siswa dalam kelompok tersebut, S2 menjumlahkan banyaknya siswa yang hanya menyukai bakso, banyaknya siswa yang hanya menyukai soto dan banyaknya siswa yang menyukai keduanya yaitu $13+8+12=33$ siswa.

S2 juga dapat menyimpulkan hasil pekerjaannya, dengan menuliskan banyaknya siswa yang hanya suka bakso adalah 13 siswa, yang hanya suka soto adalah 8 siswa dan banyak siswa dalam kelompok adalah 33 siswa. Hal tersebut diperkuat dengan wawancara dengan S2 sebagai berikut:

P: Apakah bisa dijelaskan cara anda dalam menyelesaikan soal nomor 1 ?

S2: Untuk a, kita gambarkan diagram venn, ada dua buah himpunan jadi saya gambarkan seperti ini (sambil menunjuk hasilnya).

P: Dua buah himpunan itu, himpunan apa saja?

S2: Bakso dan Soto.

P: Coba lihat di gambar! Maksud kamu menuliskan 25-12=13, ada 12 dan 20-12=8 untuk apa?

S2: Jadi 25-12=13 itu siswa yang hanya suka bakso, 12 itu, siswa yang menyukai keduanya sedangkan 20-12=8 itu siswa yang hanya menyukai soto.

P: Untuk point (b), bagaimana caranya?

S2: 25 itu, siswa yang suka bakso sedangkan 12 itu siswa yang suka keduanya. Lalau dikurang dan hasilnya 13 siswa yang hanya suka bakso.

P: Oh, jadi untuk point c, 20 itu siswa yang suka soto dan 12 itu suka keduanya?

S2: Iya pak, lalu dikurang hasilnya 8 siswa.

$P$ : Untuk poit (d), bagaimana caranya?

S2: Dijumlahkan hasil-hasil yang sudah didapatkan sebelumnya, yaitu siswa yang hanya suka bakso, siswa yang hanya suka soto dan siswa yang suka keduanya.

P: O gitu ya?

S2: Iya pak, hasilnya 33 siswa.
P: jawaban nomor 1 ini, menurut kamu sudah benar bahwa yang hanya suka bakso adalah 13 siswa, yang hanya suka soto adalah 8 siswa dan banyak siswa dalam kelompok itu adalah 33 ?

S2: sudah pak.

P: dari mana kamu yakin jawaban sudah benar?

S2: saya uji dengan cara menjumlahkan siswa yang hanya suka makan bakso saja itu 13 dengan 12 jadi 25 siswa yang suka bakso. Siswa yang hanya suka makan soto saja itu 8 dan dijumlahkan dengan 13 jadi ada 20 siswa yang suka makan soto. Kalau menghitung semua siswa dalam kelompok itu dijumlahkan siswa yang hanya suka bakso, siswa yang hanya suka soto dan siswa yang suka keduanya dilihat dari diagram venn yang sudah digambarkan.

Berdasarkan hasil jawaban siswa dan wawancara S2 pada masalah 1, maka disimpulkan bahwa, S2 sudah memiliki kemampuan pemecahan masalah dalam menyelesaikan masalah dalam kehidupan sehari-hari yang berkaitan dengan operasi himpunan (irisan).

dua buah himpunan, yaitu memahami masalah (understanding the problem), hal ini ditunjukkan dari kemampuan S2 mengidentifikasi kecukupan data untuk memecahkan masalah dengan menyebutkan informasi-informasi yang diberikan dari pertanyaan yang diajukan yakni unsur-unsur yang diketahui dari soal dan apa yang ditanyakan dari soal. Merencanakan penyelesain (deviing a plan), hal ini ditunjukkan dari kemampuan S2 menggunakan konsep operasi irisan dua buah himpunan untuk menyelesaikan masalah. Menyelesaikan sesuai rencana (carrying out the plan), S2 mampu melakukan rencana pemecahan masalah dengan menunjukkan langkah-langkah menyelesaikan masalah menggunakan strategi yang dipilih yakni operasi irisan dua buah himpunan sehingga diperoleh penyelesaian dari masalah tersebut banyaknya siswa yang suka bakso saja adalah 13 siswa, yang suka soto saja adalah 8 siswa dan banyak siswa 
dalam kelompok adalah 33 siswa. Memeriksa kembali (looking back), S2 mampu memeriksa kembali kebenaran kesimpulan yang diperoleh dengan menunjukkan cara memeriksa kebenaran jawaban yakni menguji kembali nilai yang diperoleh pada kesimpulan.

\section{Simpulan dan Saran}

\section{Simpulan}

Hasil penelitian menunjukan bahwa: 1) lintasan belajar dengan model PBL sebagai berikut: (a) Peneliti menyampaikan tujuan pembelajaran agar siswa dapat mengatur strategi dalam menyelesaikan masalah sesuai tujuan pembelajaran dan peneliti memberikan masalah nyata secara lisan dengan konteks didalam kelas tentang operasi himpunan (irisan dan gabungan); (b) Peneliti membentuk siswa dalam kelompok dan memberikan masalah terkait materi operasi himpunan (irisan dan gabungan); (c) Selanjutnya peneliti mendampingi siswa; (d) Setelah siswa selesai menyelesaikan masalah, selanjutnya dipresentasikan (e) Kemudian peneliti dan siswa mengevaluasi proses penyelesaian masalah oleh siswa. (f) Selanjutnya peneliti memberikan masalah yang berkaitan dengan masalah nyata terkait dengan materi operasi himpunan (irisan dan gabungan) yang berdasarkan hasil deskripsi dan wawanacara dengan siswa, siswa mampu mengkonstruksi pengetahuannya dalam memecahkan masalah

\section{Saran}

lain.

Sebagai bahan refrensi bagi peneliti

\section{Daftar Pustaka}

Wardhani, S. (2010). Implikasi Karakteristik Matematika dalam Pencapaian Tujuan Mata pelajaran Matematika di
SMP/MTs. Yogyakarta: Departemen Pendidikan Nasional PPPPTK.

Setyorini, dkk. (2011), Penerapan Model Problem Based Learning untuk Meningkatkan Kemampuan Berpikir Kritis Siswa SMP, Jurnal Pendidikan Fisika Indonesia (JPFI).

Trianto. (2007). Pengembangan Perangkat dalam Teori dan Praktek. Surabaya: Prestasi Pustaka.

Shadiq, Fajar. 2009. Kemahiran Matematika. Disampaikan pada diklat instruktur pengembangan matematika SMA jenjang lanjut. PPPG Yogyakarta.

Polya, G. (1973). How To Solve It "A New Aspect Of Mathematical Method" Second Edition. USA: Princeton Univesity Press.

Sugiyono. 2008. Metode Penelitian Kuantitatif, Kualitatif, dan $R \quad \& \quad D$. Bandung: Alfabeta.

Plomp (2007). Educational Design Research: An Introduction, dalam An Introduction to Educational Research. Enschede, Netherland: National Institute for Curruculum Development

Gravemeijer dan Cobb (2006). Design Research from a Learning Perpective, dalam Education Design Research. New York : Routledge.

Van Den Akker, J et all., (2006). Introduction Eduactional Design Research. New York: Routledge 